\title{
Evaluation of environmental impact of cement production in Algeria using life cycle assessment
}

\author{
S. Boughrara, M. Chedri, K. Louhab* \\ Food Technology Research Laboratory, University of Boumerdes, 35000 - Boumerdes, Algeria \\ *E-mail address: louhab_ka@yahoo.fr
}

\begin{abstract}
The aim of this study is the use of Life Cycle Assessment, to evaluate the impact generated by cement manufactory situated in Sour EL Ghozlane town in Algeria country, which use the dry process to produce cement Portland.

The LCA method is used for compiling and examining the inputs and outputs of energy, raw material and environmental impacts directly attributable to the manufacture and functioning of a product throughout its life. It is also used to determine element and energy contributing to each impact evaluated.

Potentials impacts are evaluated using the SimaProV.7.1 software and IMPACT2000+ method in this study.
\end{abstract}

Keyword: Life Cycle Assessment; SimaPro.7.1; Impact 2000+; cement Portland; dry process

\section{INTRODUCTION}

Life cycle assessment (LCA) is an important tool used to evaluate and identify the environmental impacts related to a product, service or system from a holistic standpoint that incorporates all known potential environmental impacts and follows the product, service or system from cradle to grave. It is used to understand total energy consumption, identifying energy saving opportunities, and informing decision-makers.

The LCA method has described in the ISO standards 14040 and 14044. It has developed quickly during the 1990s and has reached a definite level of harmonization and standardization. An LCA study consists of four phases: goal and scope definition, inventory analysis, impacts assessment and interpretation [1].

The LCA of a Portland cement concrete road takes into a count the raw materials and energy used in making the cement as well as the emissions from the cement manufacturing process. It includes the energy and resources consumed in mixing, transporting and the environmental consequences [2].

Regarding to the LCA of the cement industry, Huntzinger and al. [3] describes that the production of cement involves the consumption of large quantities of raw materials, energy and heat. The manufacturing process is very complex, involving a large number of materials, pyro processing (wet and dry kiln, preheating....), and fuel sources. 


\subsection{Cement manufacturing process}

Raw materials should be mixed precisely to manufacture the cement. The cement clincker requires appropriate amount of compositions of the elements calcium, silicon, aluminum and iron. All these raw materials together with the fuel as an energy consumption must be combined to form the typical clinker composition [4].

In rotary kiln, the raw materials are calcined at temperature varying between $700 \mathrm{C}^{\circ}$ and $900^{\circ} \mathrm{C}$, which is a combination of alumina, ferric oxide and silica with lime. Between 900$1200^{\circ} \mathrm{C}$, there is formation of clinker. The clinckerisation process is following by the cooling stage.

\section{MATERIAL AND METHODS}

\subsection{Life cycle assessment methodology}

Life cycle assessment (LCA) is a systematic way of evaluating the environmental impacts arising from resources depletion and process emissions associated with a product or service [2]. It is a method of evaluation used to assess the environmental impacts of technologies from "cradle to grave" it has the ability to evaluate the materials and energy efficiency of a system, and to identify pollution. It consider the environmental impact of a product during its life cycle: starting with raw material acquisition, through production and use and final disposal.

\subsection{Goal and scope, functional unit and system boundaries}

The goal of the present study is to assess and the environmental performance of cement manufacturing by dry process. The model focuses on all steps or stages of cement production (blinding and grinding of clinker and addition of mineral components to produce cement). The functional unit of analysis in this study is the production of one ton of cement.

\subsection{Data quality}

The study is based on the process data supplied by cement production in Algerian manufactories (SOUR ELGHOZLANE using dry process). Data used for this study is based on data records from the plants. In this study, we have used the SimaPro7.1 software to evaluate the environmental impact of inventory aspects using IMPACT 2000+ method Inventory data for raw materials and electricity and heat generated by fuel (natural gas in this case) is obtained from those factories and from SimaPro.7, software databases (table 1-show raw materials and energy resources used in this factory). 
Table 1. Inventory of dry process of cement production.

\begin{tabular}{c|c|c}
\hline Compound & Quantity & unit \\
\hline Iron & 0,02 & Ton/Ton cement \\
\hline Sand & 0,06 & Ton/Ton cement \\
\hline Limeston & 1,36 & Ton/Ton cement \\
\hline clay & 0,10 & Ton/Ton cement \\
\hline Clinker & 0.96 & Ton/Ton cement \\
\hline gypsum & 0,05 & Ton/Ton cement \\
\hline tuff & 0,07 & Ton/Ton cement \\
\hline Electricity & 106.13 & $\mathrm{KWh} /$ Ton cement \\
\hline Natural gaz & 100.13 & $\mathrm{M}^{3} /$ ton cement \\
\hline gas-oil & 1.64 & $\mathrm{~L} /$ Ton cement \\
\hline oil & 1.09 & $\mathrm{~L} /$ Ton cement \\
\hline Grease & 0.13 & $\mathrm{Kg} /$ Ton cement \\
\hline Water & 0.33 & $\mathrm{Kg} /$ Ton cement \\
\hline $\mathrm{CO}_{\mathrm{NO}}$ & 1,85 & $\mathrm{Kg} /$ Ton cement \\
\hline Particule & 0,51 & $\mathrm{Kg} /$ Ton cement \\
\hline $\mathrm{CO}_{2}$ & 0,1 & $\mathrm{Kg} /$ Ton cement \\
\hline
\end{tabular}

\subsection{Impacts assessment}

The impacts considered in this study are shown in table 2:

-Global warming expressed on $\mathrm{Eq} \mathrm{kg} \mathrm{CO} 2$

-Aquatic eutrophication expressed on eq $\mathrm{kg} \mathrm{PO}_{4}{ }^{-3}$

-Aquatic acidification expressed on Eqkg $\mathrm{SO}_{2}$

-Terrestrial acid/nitrification expressed on Eq.kg $\mathrm{SO}_{2}$ )

-Respiratory organic expressed on Eq. $\mathrm{kgC}_{2} \mathrm{H}_{4}$

-Ozone layer depletion expressed on Eq.kgCFC-11

-Respiratory inorganic expressed on Eq.KgPM2.5)

-Carcinogen expressed on Eq. $\mathrm{kgC}_{2} \mathrm{H}_{3} \mathrm{Cl}$

Table 2. Damages categories and impacts categories assessed.

\begin{tabular}{|c|c|c|c|c|c|c|c|}
\hline \multicolumn{8}{|c|}{ Damage categories } \\
\hline \multicolumn{2}{|c|}{$\begin{array}{l}\text { Humanhealth } \\
\text { (DALY) }\end{array}$} & \multicolumn{2}{|c|}{$\begin{array}{l}\text { Ecosystem quality } \\
\left(P D F^{*} m 2^{*} y r\right)\end{array}$} & \multicolumn{2}{|c|}{$\begin{array}{c}\text { Climate change } \\
\left(\mathrm{Eq} \mathrm{Kg} \mathrm{CO}_{2}\right)\end{array}$} & \multicolumn{2}{|c|}{$\begin{array}{c}\text { Ressources } \\
\text { (MJ Primaire) }\end{array}$} \\
\hline \multicolumn{2}{|c|}{$1,445 E-7$} & \multicolumn{2}{|c|}{$89.7 E-4$} & \multicolumn{2}{|c|}{0,882087} & \multicolumn{2}{|c|}{5,77} \\
\hline \multicolumn{8}{|c|}{ Impacts categories } \\
\hline $\begin{array}{l}\text { Carcinogen } \\
\text { Eq. } \mathrm{kgC}_{2} \mathrm{H}_{3} \mathrm{Cl}\end{array}$ & $\begin{array}{l}\text { Respiratory } \\
\text { inorganic } \\
\text { Eq.KgPM2.5 }\end{array}$ & $\begin{array}{l}\text { Ozone layer } \\
\text { depletion } \\
\text { Eq.kgCFC-11 }\end{array}$ & $\begin{array}{l}\text { Respiratory } \\
\text { organic } \\
\text { Eq.kgC }_{2} H_{4}\end{array}$ & $\begin{array}{l}\text { Terrestrial } \\
\text { acid/nutr } \\
\text { Eq.kg SO}\end{array}$ & $\begin{array}{c}\text { Aquatic } \\
\text { acidification eqkg } \\
\mathrm{SO}_{2}\end{array}$ & $\begin{array}{c}\text { Aquatic } \\
\text { eutrophication } \\
\text { Eq.kg } \mathrm{PO}_{4}^{-3}\end{array}$ & $\begin{array}{c}\text { Global } \\
\text { warming } \\
\text { Eq.kgCO }\end{array}$ \\
\hline $13.41 E-4$ & $19.93 E-5$ & $7,44 E-9$ & $4,92 E-5$ & $57.06 E-4$ & $8.67 E-4$ & $7,86 E-7$ & 0,882 \\
\hline
\end{tabular}


Table 3. Contribution of energy to impact.

\begin{tabular}{|c|c|c|c|}
\hline $\begin{array}{c}\text { Energy } \\
\text { Categories }\end{array}$ & Naturel gaz & Electricity & Diesel \\
\hline \multicolumn{4}{|c|}{ Damage categories } \\
\hline Humanhealth (DALY) & $1,538 E-8$ & $1,946 E-8$ & $1,131 E-9$ \\
\hline Ecosystem quality $\left(P D F^{*} m 2{ }^{*} y r\right)$ & $14.468 E-4$ & $29.833 E-4$ & $6,218 E-5$ \\
\hline Climate change $\left(\mathrm{Eq} \mathrm{Kg} \mathrm{CO}_{2}\right)$ & $29.615 E-3$ & $82.846 E-3$ & 0,0007207377 \\
\hline Ressources (MJ Primaire) & 4,671 & 1,007 & $92.434 E-3$ \\
\hline \multicolumn{4}{|c|}{ Impact categories } \\
\hline Carcinogène $\left(\mathrm{Eq} \cdot \mathrm{kgC} \mathrm{C}_{2} \mathrm{H}_{3} \mathrm{Cl}\right)$ & $37.926 E-5$ & $82.5 E-5$ & \\
\hline Respiratory inorganic (Eq.KgPM2.5) & $1,994 E-5$ & $2,344 E-5$ & \\
\hline Ozone layer depletion (Eq.kgCFC-11) & $2,113 E-9$ & $1,885 E-10$ & \\
\hline Respiratory organic $\left(E q . k g C_{2} H_{4}\right)$ & $3,145 E-5$ & $9,286 E-6$ & \\
\hline Terrestrial acid/nutri (Eq.kg SO & $47.501 E-5$ & $89.626 E-5$ & \\
\hline Aquatic acidification (Eq. $\mathrm{kg} \mathrm{SO} \mathrm{S}_{2}$ ) & $17.448 E-5$ & $13.892 E-5$ & \\
\hline Global warming (Eq.kg $\left.\mathrm{CO}_{2}\right)$ & $29.615 E-3$ & $82.846 E-3$ & \\
\hline
\end{tabular}

\section{RESULTS AND DISCUSSION}

Table 2 shows all damage categories and impact categories generated by dry process, in this evaluation, we have assessed four damage: human health, ecosystem quality, climate change and resources. Each damage has it impact category: for example damage human health, have tow impacts categories: carcinogen and respiratory inorganic. It is observed that resources cause major damage, it have an effect on global warming, aquatic eutrophication, and climate change.

Damage of resources is the greatest, it generate two impacts categories; global warming at $0.882 \mathrm{eq} \mathrm{kg} \mathrm{CO}_{2}$, and aquatic eutrophication at $7.86 \mathrm{E}-7 \mathrm{Eq} \cdot \mathrm{kg} \mathrm{PO}_{4}{ }^{-3}$, that's result from using resource such as natural gaz as source of heat necessary to clinckerisation and process. This process is following by height quantity of gases emitted as $\mathrm{CO}_{2}, \mathrm{SO}_{2}$, and $\mathrm{NO}_{\mathrm{X}}$, which are the results of combustion process.

Table 4. Contribution of energy to impacts categories.

\begin{tabular}{c|c|c}
\hline Consommation & Natural gaz & Electricity \\
Catégories & & $61.5 \%$ \\
\hline Carcinogène $\left(E q . \mathrm{kg} \mathrm{C}_{2} \mathrm{H}_{3} \mathrm{Cl}\right)$ & $28.5 \%$ & $11 \%$ \\
\hline Respiratory inorganic $(E q . \mathrm{KgPM} .5)$ & $11.5 \%$ & $2.5 \%$ \\
\hline Ozone layer depletion $(E q . \mathrm{kgCFC}-11)$ & $12 \%$ & $18.5 \%$ \\
\hline Respiratory organic $\left(E q . \mathrm{kgC} \mathrm{C}_{4}\right)$ & $62.5 \%$ & $15 \%$ \\
\hline Terrestrial acid/nutri $\left(E q . \mathrm{kg} \mathrm{SO} \mathrm{SO}_{2}\right)$ & $85 \%$ & $15.5 \%$ \\
\hline Aquatic acidification $\left(E q . \mathrm{kg} \mathrm{SO} \mathrm{SO}_{2}\right)$ & $20.5 \%$ & $9 \%$ \\
\hline Global warming $\left(E q . \mathrm{kgCO} \mathrm{CO}_{2}\right)$ & $3.2 \%$ & \\
\hline
\end{tabular}

Table 4 shows contribution of energy; natural gaz and electricity to each impact categories. It has observed that, natural gaz at $85 \%$ to terrestrial acidification and nitrification 
and at $62.5 \%$ to respiratory organic which is due to gaz emission $\mathrm{NO}_{\mathrm{X}}, \mathrm{CO}_{2}$ and $\mathrm{SO}_{2}$. Figure 1resumes the contribution of energy to impacts categories.

A study done by Ahmed Abdelmotaleb and al [5], on effect of fuel on life cycle of Egyptian cement industry: environmental impact assessment approach, results show that the decision of replacing the existing used fuels in cement industry by coal will carry an additional burden on the environment approximately by $20 \%$. Global warming and respiratory inorganic recorded highly negative impacts of $20 \%$ and $25 \%$ respectively when using he coal compared with other fuels type. The damage human health is dominated when using the coal with a relative contribution of $30 \%$.

In our study, for human health damage, carcinogen and respiratory inorganic, natural gaz and electricity contribute respectably at $(28.5 \%, 61.5 \%)$ and $(11.5 \% 11 \%)$. This damage is posed by contamination air, sol and vegetation. Marta Schuhmacher and al [6] in their study show that the incremental risk of mortality /morbidity produced by $\mathrm{PM}$, and $\mathrm{SO}_{2}, \mathrm{NO}_{2}$, does not mean any important additional health risk for the population living in the area under evaluation. The highest annual incremental risk corresponded to particles', with mean concentrations of $4.6^{*} 10^{-5}$ and $3.8^{*} 10^{-4}$ for chronic mortality and morbidity, respectively

$\left(1.6^{*} 10^{-4}\right.$ and $\left.1.3^{*} 10^{-3}\right)$. For a population of 80.976 inhabitants, annual increments of 37 subjects have been estimated to show health effects due to emission from plant. In relation to $\mathrm{PCDD} / \mathrm{Fs}$, the inhalation cancer risk in this case is for maximum concentration.

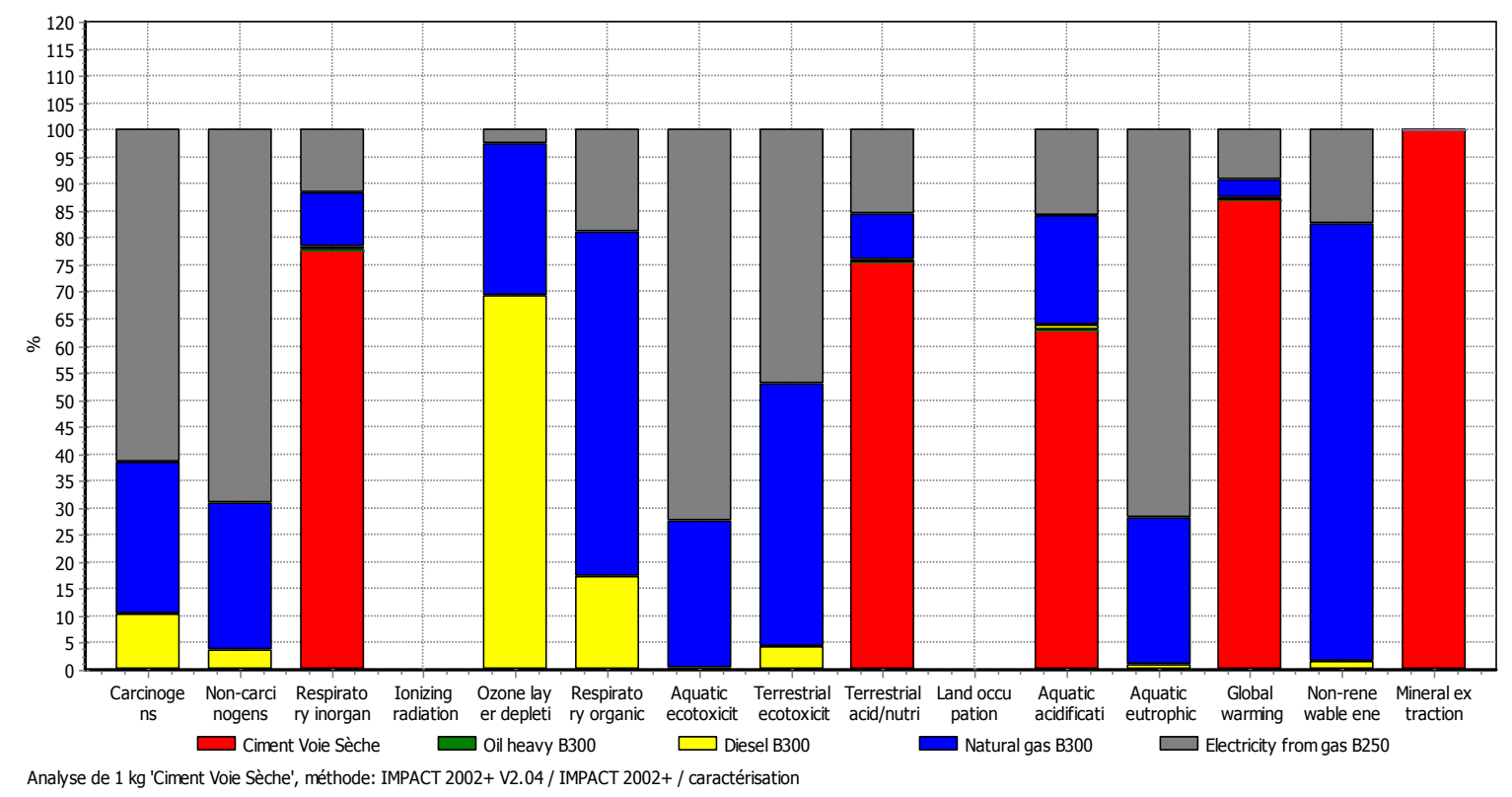

Figure 1. Contribution of energy to impacts categories.

\section{CONCLUSION}

Life cycle assessment is a useful tool for evaluating the environmental impact generated by system, product or service. In this case we have used LCA in order to determine and evaluate the impacts generated by cement production in Algeria, using dry process, with this 
tool and using SimaPro7.1 and IMPACT 2000+, we have assessed all damages categories with their impacts categories, and contribution of energy used to those impacts.

In the present study, natural gaz and electricity contribute, to each impact category such as carcinogen, respiratory organic, global warming... because during the process of production, it has generated a most quantity of gases and particles emitted through atmosphere.

So, we can make intervention in order to reduce the impact categories, by replacing energy used or minimization of energy and raw material consumption. So this tool helps to make decision in politic of environmental management.

\section{References}

[1] Environment management- life cycle assessment- principals and framework (2006)

[2] Michael N, Jan C, Martha G. Environmental life cycle inventory of portland cement and concrete, Serial number 2140, World Cement April 1997.

[3] Huntzinger, N. T.D. Eatmon, "A life cycle assessment of Portland cement manufacturing: comparing the traditional process with alternative technologies" Journal of Cleaner Production, vol 17, $\mathrm{n}^{\circ}$ 7, pp 668-775 May 2009.

[4] Sogut H. Oktay Z. "Energetic and exergetic assessment of a trass mill processs in a cement plant, "Energy conservation and management", vol 50, PP.2316-2323, 2009.

[5] Ahmed AbdelMotaleb M, Abdelazim M N, Mahmoud F B, Mona G, Effect of fuel on life cycle of Egyptian cement industry: environmental impact assessment approach, the asian conference on soustainability, Energy and the environnement 2014-07- 16 official conference proceeding 0785 . The international academic forum, www.iafor.org

[6] Marta S, Jose L, Domingo, Josepa G, Pollution emitted by cement plant: health risks for the population living in the neighborhood. Environmental Research 95 (2004)198-206. 